\title{
Childhood Retardation Resulting in Reduction of Adult Body Size Due to Lesser Adolescent Skeletal Delay
}

\author{
A. ROBERTO FRISANCHO, ${ }^{1}$ STANLEY M. GARN ${ }^{1}$ AND \\ WERNER ASCOLI 2 \\ ${ }^{1}$ Center for Human Growth and Development and Department of \\ Anthropology, University of Michigan, Ann Arbor 48104, and \\ ${ }^{2}$ Instituto de Nutrición de Centro América y Panamá (INCAP)
}

\begin{abstract}
The skeletal maturation of 7972 rural children from the six Central American nations, aged one month through 22 years, is evaluated. The results suggest that retardation in skeletal maturation during childhood is significantly greater than during adolescence, while growth in body size shows a progressive delay from infancy through adolescence. In other words, the apparent improvement in skeletal maturation during adolescence is not associated with an equivalent "catch-up" in body size. Similarly, prolongation of the period of growth does not fully compensate for the slow rate of growth. It is postulated that the small stature in Central America is related to the marked childhood retardation and to the fact that during adolescence, the timing of skeletal maturation is less affected than growth in size.
\end{abstract}

Individual and population differences in adult body size result through the interaction of genetic and environmental factors operating at the developmental level. From a variety of studies it is known that chronic malnutrition decreases the rate of growth in size and retards skeletal development. However, it is not known whether the diminution in the rate of growth in size and the delays in skeletal maturation are comparable under conditions of caloric and protein insufficiency. Furthermore, the relationship between growth retardation and attainment of adult body size has not been ascertained. With this purpose in view, we have studied data on skeletal development and body size of selected rural populations from the six Central American nations. As shown from detailed household data, the caloric and protein intakes of these populations are far below the USA standards and those recommended by the Instituto de Nutrición de Centro América y Panamá for Central American populations (Evaluación Nutricional de la Población de Centro América y Panamá, INCAP, '69). The aim of this investigation, therefore, is to determine whether skeletal maturation and growth are equally delayed by malnutrition. In this manner, the relationship of childhood and adolescent retardation to the attainment of adult body size of Central American populations is also studied.

\section{MATERIALS AND METHODS}

\section{Sample}

This study is based upon evaluation of ossification timing and epiphyseal union of the hand and wrist derived from standardized 36-inch postero-anterior hand radiographs from the six Central American nations. A cross-sectional sample of 7972 subjects, aged 0 to 22 years, is represented in this study. The distribution by country, age and sex is given in table 1 .

These subjects were participants in a nutritional survey sponsored by the Nutrition Section of the Office of International Research (OIR) of the National Institutes of Health and conducted by the Instituto de Nutrición de Centro América y Panamá (Evaluación Nutricional de la Población de Centro América y Panamá, INCAP, '69). The subjects included in the present study were derived from the rural communities of each country. In each rural community, a systematic random sample of households was included in the survey.

\section{Dietary intakes}

The detailed results of the dietary survey of the six Central American nations have already been reported elsewhere (Evaluación Nutricional de la Población de Centro América y Panamá, INCAP, '69). As shown in table 2 , the caloric and protein 
A. R. FRISANCHO, S. M. GARN AND W. ASCOLI

TABLE 1

Distribution by age and sex of Central American rural populations

\begin{tabular}{|c|c|c|c|c|c|c|c|c|c|c|c|c|}
\hline \multirow{2}{*}{$\begin{array}{c}\text { Age } \\
\text { Group }\end{array}$} & \multicolumn{2}{|c|}{ Costa Rica } & \multicolumn{2}{|c|}{ El Salvador } & \multicolumn{2}{|c|}{ Guatemala } & \multicolumn{2}{|c|}{ Honduras } & \multicolumn{2}{|c|}{ Nicaragua } & \multicolumn{2}{|c|}{ Panama } \\
\hline & $\stackrel{\mathbf{M}}{\mathbf{N}}$ & $\underset{\mathbf{N}}{\mathbf{F}}$ & $\stackrel{M}{N}$ & $\underset{\mathbf{N}}{\mathbf{F}}$ & $\mathbf{M}$ & $\underset{\mathbf{N}}{\mathbf{F}}$ & $\begin{array}{l}\mathbf{M} \\
\mathbf{N}\end{array}$ & $\underset{\mathbf{N}}{\mathbf{F}}$ & $\stackrel{\mathbf{M}}{\mathbf{N}}$ & $\stackrel{F}{N}$ & $\mathrm{M}$ & $\underset{\mathbf{N}}{\mathbf{F}}$ \\
\hline $0.0-0.4$ & 19 & 20 & 5 & 4 & 27 & 32 & 20 & 24 & 17 & 28 & 25 & 20 \\
\hline $0.5-0.9$ & 9 & 15 & 5 & 6 & 8 & 28 & 23 & 15 & 27 & 15 & 15 & 23 \\
\hline $1.0-1.4$ & 19 & 14 & 9 & 6 & 30 & 19 & 18 & 23 & 15 & 14 & 12 & 13 \\
\hline $1.5-1.9$ & 7 & 12 & 16 & 9 & 25 & 28 & 12 & 20 & 10 & 19 & 11 & 15 \\
\hline $2.0-2.4$ & 17 & 22 & 8 & 10 & 13 & 15 & 22 & 11 & 12 & 7 & 11 & 14 \\
\hline $2.5-2.9$ & 10 & 18 & 15 & 13 & 23 & 26 & 23 & 20 & 11 & 14 & 21 & 19 \\
\hline $3.0-3.4$ & 18 & 12 & 10 & 10 & 32 & 22 & 12 & 17 & 14 & 18 & 15 & 7 \\
\hline $3.5-3.9$ & 13 & 20 & 18 & 15 & 24 & 22 & 16 & 17 & 21 & 21 & 23 & 23 \\
\hline $4.0-4.4$ & 21 & 29 & 18 & 10 & 33 & 26 & 16 & 21 & 22 & 24 & 28 & 30 \\
\hline $4.5-4.9$ & 31 & 34 & 24 & 17 & 39 & 42 & 49 & 42 & 27 & 19 & 31 & 36 \\
\hline $5.0-5.9$ & 33 & 23 & 34 & 27 & 50 & 37 & 38 & 34 & 35 & 52 & 37 & 42 \\
\hline $6.0-6.9$ & 34 & 29 & 33 & 25 & 53 & 40 & 34 & 39 & 22 & 25 & 27 & 30 \\
\hline $7.0-7.9$ & 29 & 34 & 36 & 28 & 57 & 35 & 28 & 38 & 35 & 38 & 36 & 46 \\
\hline $8.0-8.9$ & 30 & 30 & 18 & 29 & 41 & 46 & 27 & 40 & 25 & 26 & 29 & 35 \\
\hline $9.0-9.9$ & 30 & 34 & 26 & 29 & 42 & 38 & 35 & 34 & 27 & 31 & 27 & 41 \\
\hline $10.0-10.9$ & 24 & 27 & 25 & 23 & 36 & 31 & 33 & 32 & 27 & 21 & 27 & 33 \\
\hline $11.0-11.9$ & 32 & 39 & 27 & 20 & 47 & 42 & 29 & 38 & 27 & 29 & 31 & 33 \\
\hline $12.0-12.9$ & 16 & 31 & 16 & 17 & 37 & 26 & 27 & 22 & 13 & 26 & 39 & 36 \\
\hline $13.0-13.9$ & 22 & 20 & 23 & 21 & 17 & 23 & 29 & 22 & 26 & 31 & 21 & 30 \\
\hline $14.0-14.9$ & 14 & 19 & 16 & 22 & 21 & 18 & 17 & 25 & 19 & 17 & 18 & 27 \\
\hline $15.0-15.9$ & 16 & 24 & 21 & 16 & 9 & 20 & 23 & 14 & 13 & 20 & 20 & 20 \\
\hline $16.0-16.9$ & 21 & 14 & 54 & 15 & 16 & 18 & 15 & 19 & 16 & 10 & 12 & 18 \\
\hline $17.0-17.9$ & 17 & 29 & 86 & 18 & 30 & 25 & 32 & 18 & 24 & 24 & 12 & 12 \\
\hline $18.0-18.9$ & 13 & 19 & 71 & 19 & 46 & 22 & 26 & 11 & 16 & 19 & 17 & 19 \\
\hline $19.0-22.0$ & 43 & 67 & 173 & 30 & 93 & 97 & 114 & 86 & 103 & 57 & 98 & 72 \\
\hline Total: & 538 & 635 & 787 & 439 & 849 & 778 & 718 & 682 & 604 & 605 & 643 & 694 \\
\hline
\end{tabular}

TABLE 2

Average individual daily caloric and protein intakes derived from household intakes of rural areas from the six Central American nations

\begin{tabular}{|c|c|c|c|c|c|c|c|}
\hline & \multirow{3}{*}{$\begin{array}{l}\text { No. } \\
\text { families }\end{array}$} & \multicolumn{2}{|c|}{ Individual average 1} & \multicolumn{4}{|c|}{$\begin{array}{l}\text { Percentage of families whose } \\
\text { daily intake is less than }\end{array}$} \\
\hline & & \multirow{2}{*}{$\overline{\text { Calories }}$} & \multirow{2}{*}{ Protein 2} & \multicolumn{3}{|c|}{ Calories 2} & \multirow{2}{*}{$\frac{\text { Protein }}{38 \mathrm{gm}}$} \\
\hline & & & & 1100 & 1500 & 1900 & \\
\hline & & & $g m$ & $\%$ & $\%$ & $\%$ & $\%$ \\
\hline Costa Rica & 456 & 1894 & 53.6 & 6 & 25 & 49 & 23 \\
\hline El Salvador & 293 & 2146 & 67.9 & 6 & 16 & 28 & 9 \\
\hline Guatemala & 203 & 1994 & 60.4 & 5 & 10 & 20 & 20 \\
\hline Honduras & 331 & 1832 & 58.0 & 14 & 70 & 46 & 13 \\
\hline Nicaragua & 355 & 1986 & 64.4 & 6 & 24 & 45 & 70 \\
\hline Panama & 361 & 2089 & 60.1 & 3 & 15 & 36 & 16 \\
\hline
\end{tabular}

1 Adapted from Evaluación Nutricional de la Población de Centro América y Panamá. Instituto de Nutrición de Centro América y Panamá, INCAP, Vol. 25-30, Guatemala City, Guatemala, 1969.

2 These caloric values correspond to the 50,70 and $90 \%$ of the average recommended intakes for Central American populations. Similarly, $38 \mathrm{gm}$ of protein corresponds to the $70 \%$ of the average recommended intakes.

intakes of a large proportion of Central American families are well below the average recommended intakes for both the USA and Central American nations. Furthermore, table 3 indicates that nearly $50 \%$ of the caloric and protein intake is derived from cereals. These cereals consist mostly of corn and rice which are products known to be of low protein quality due to deficiency in certain essential amino acids (such as lysine and tryptophan). For example, in Guatemala, $17 \%$ of the 203 rural families had animal protein intakes ranging from 0 to $2.5 \mathrm{gm} /$ person/day, while the majority had an intake of between 5 and $15 \mathrm{gm} /$ person/day. These sur- 


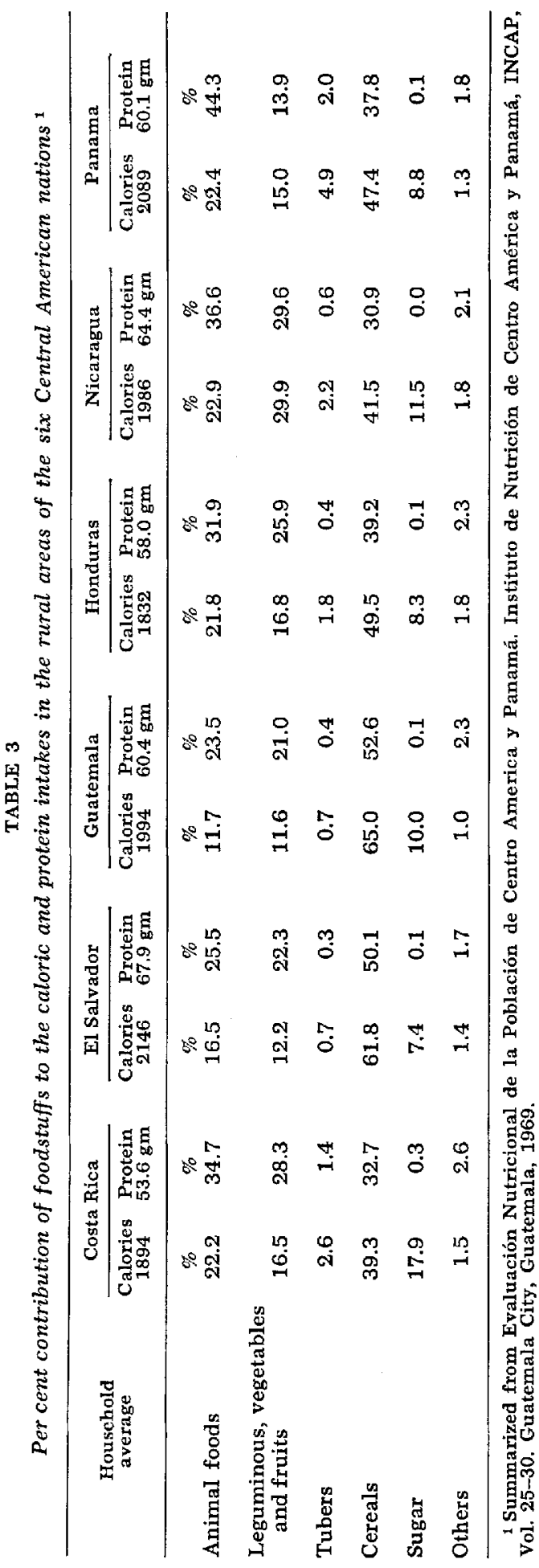

vey data are confirmed by very low daily levels of urinary nitrogen excretion. Rural children in Guatemala, between the ages of zero and three years, have 24-hour average urine nitrogen excretion of $2.0 \mathrm{gm}$, while the urban group has an average nitrogen excretion of $4.2 \mathrm{gm}$ and subjects over 14 years have an average excretion of 6.0 and $8.6 \mathrm{gm} /$ person/day in the rural and urban areas, respectively. Thus, protein deficiency is found to be as prevalent among children as in adolescents. Analysis of food distribution in the households also indicated that children are disproportionately deprived of adequate caloric intakes. These dietary deficiencies are complicated by infectious diseases affecting both the children and adults, poor sanitary conditions, faulty concepts of disease causation, and erroneous concepts about nutritive value of foodstuffs (Béhar, '68).

\section{Review of radiographs}

The postero-anterior radiographs of the left hand and wrist of every subject were reviewed by trained observers. The 29 postnatal ossification centers (excluding the pisiform) were recorded separately as "present" or "absent" when radiographically visible, irrespective of their size. The adductor sesamoid was considered present when radiographically visible, irrespective of its size, in subjects in whom fusion of the distal segment of digits or metacarpal had not occurred. The epiphyses of the distal, middle and proximal segments of the digits and epiphysis of the metacarpals were considered fused when the "epiphyseal line" between diaphysis and epiphysis disappeared. Tests of inter-observer reliability gave correlations in excess of 0.96 .

\section{Determination of percentiles}

The percentile distribution for the ageat-appearance of each ossification center and age at epiphyseal fusion was derived from the total ungrouped sex-specific sample. These calculations were made through a specially designed computerized program. The program constructs the cumulative frequency curve of a particular ossification center from age 0 to 18 years or complete epiphyseal fusion from age 10 to 22 years. The resulting curve approximates a normal distribution and is used to deter- 
mine the age at which 1 to $99 \%$ of the sample has the particular ossification center present (or shows complete epiphyseal fusion). From this percentile distribution, the fiftieth percentile was uniformly used for the comparison of ossification timing and complete epiphyseal union to the USA standards (Garn, Rohmann and Apfelbaum, '61; Garn, Rohmann and Silverman, '67).

\section{Maturity criteria}

Based upon previous investigations on skeletal maturation during childhood (Flory, '36; Todd, '37; Sontag, Snell and Anderson, '39; Francis, '39; Francis and Werle, '39; Flecker, '42; Christie, '49; Reynolds and Asakawa, '51; MacKay, '52; Sutow, '53; Greulich and Pyle, '66; Garn and Rohmann, '60; Thsala, Kantero and Backstrom, '66; Lee et al., '68) and during adolescence (Baldwin, Busby and Gayside, '28; Hellman, '28; Ruckensteiner, '31; Buehl and Pyle, '42; Hansman and Maresh, '61; Garn and Rohmann, '62; Björk and Helm, '67; Frisancho, Garn and Rohmann, '69), we have studied the maturation of the hand-wrist in terms of four categories as follows:

(1) Centers of infancy represented by the capitate and hamate.

(2) Centers of early childhood marked by the appearance of the epiphyses of the distal segment of the radius, epiphyses of the metacarpals, epiphyses of the proximal, middle and distal segment of the digits, and the triquetral.

(3) Centers of later childhood indicated by the appearance of the lunate, scaphoid, trapezium, trapezoid and epiphysis of the distal segment of the thumb.

(4) Markers of adolescence indicated by the appearance of the adductor sesamoid, complete epiphyseal fusion of the distal digits and complete epiphyseal fusion of the metacarpals.

\section{Calculation of relative delay}

The percent delay in skeletal maturation of the Central American samples with respect to the USA standards for the age-atappearance of the hand-wrist centers (Garn, Rohmann and Silverman, '67) and for the age at complete epiphyseal fusion
(Garn, Rohmann and Apfelbaum, '61) has been calculated by the following formula:

$\begin{aligned} & \text { Percent Delay } \\ & \text { Conception }\end{aligned}=\left(\frac{\text { Group Median }+0.75}{\text { USA Median }+0.75}-1.0\right) 100$ where 0.75 represents the nine months of intrauterine development (i.e., conception is taken as time zero). Thus, the per cent delay has been corrected for conception. In this manner, artificially high delays of the early-appearing centers are prevented. For example, if a particular center is present at birth in the standard and if it appears at three months in another population, there would be an unrealistic 200 per cent delay. By employing the correction, this computational artifact is eliminated. Thus, according to this formula, the delay (corrected for conception) of the distal radius in Costa Rican females would be 12 per cent. That is :

$$
\begin{gathered}
\left(\frac{1.01+0.75}{0.82+0.75}-1.0\right) 100=12 \\
\text { RESULTS } \\
\text { Skeletal maturation }
\end{gathered}
$$

\section{Skeletal maturation}

Tables 4 and 5 summarize the median values for the markers of infancy, early childhood, later childhood and adolescence of Central American children. In addition, these tables also present the skeletal delay expressed as per cent (conception-corrected) delay from the USA standards. From these data and as illustrated in figure 1, viewing both sexes together, the following findings are evident:

a. During infancy, the retardation in skeletal maturation ranges from 1 to $14 \%$.

b. During early and later childhood, the retardation ranges from $12 \%$ and reaches a high of $39 \%$.

c. During adolescence, the maturity delay ranges from $5 \%$ and does not exceed $9 \%$.

Thus, Central American children, when compared to the USA standards, show the greatest delay during childhood and the least delay during adolescence and the first year of age. Furthermore, the delay during infancy, childhood and adolescence in both males and females is of the same magnitude. 


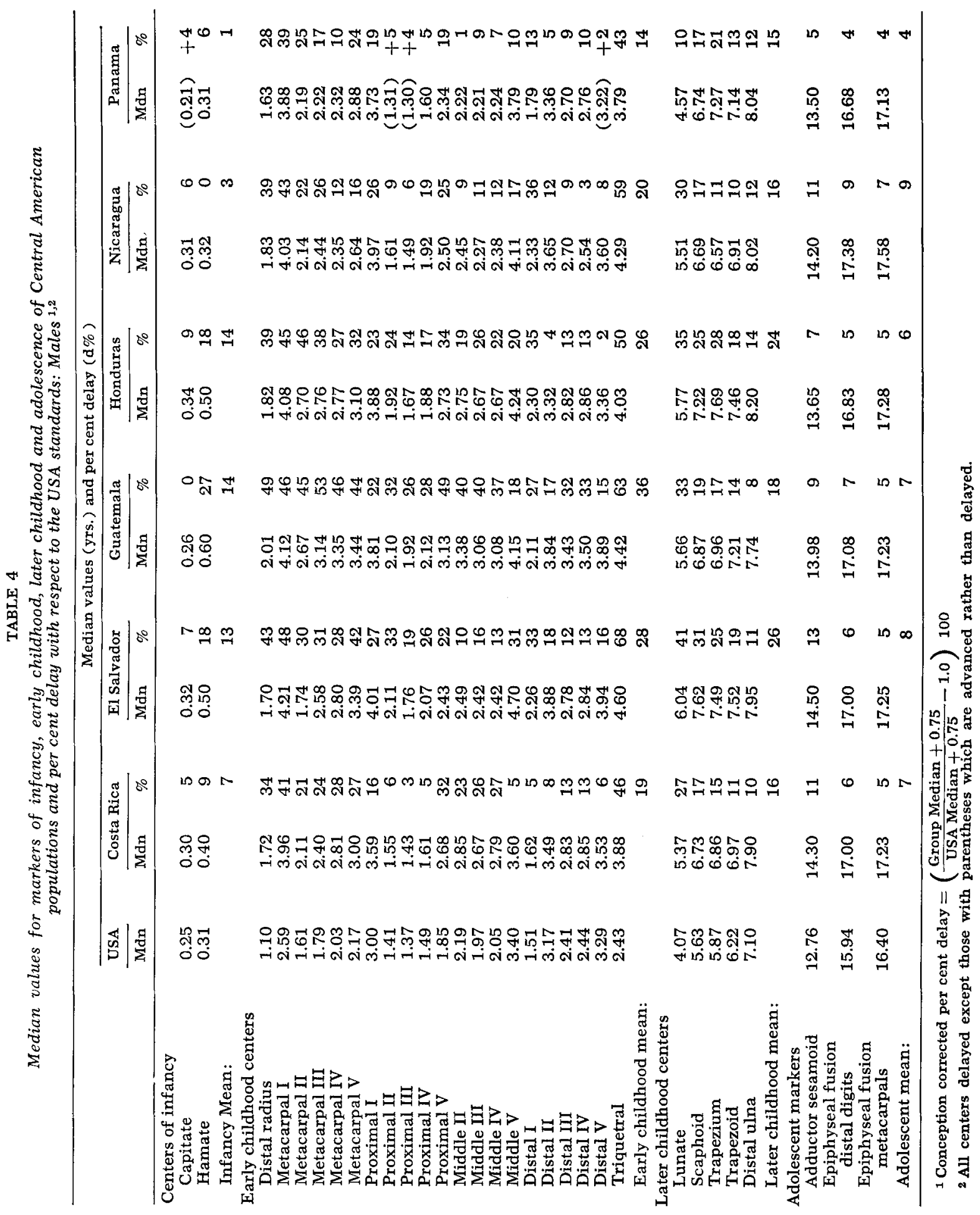




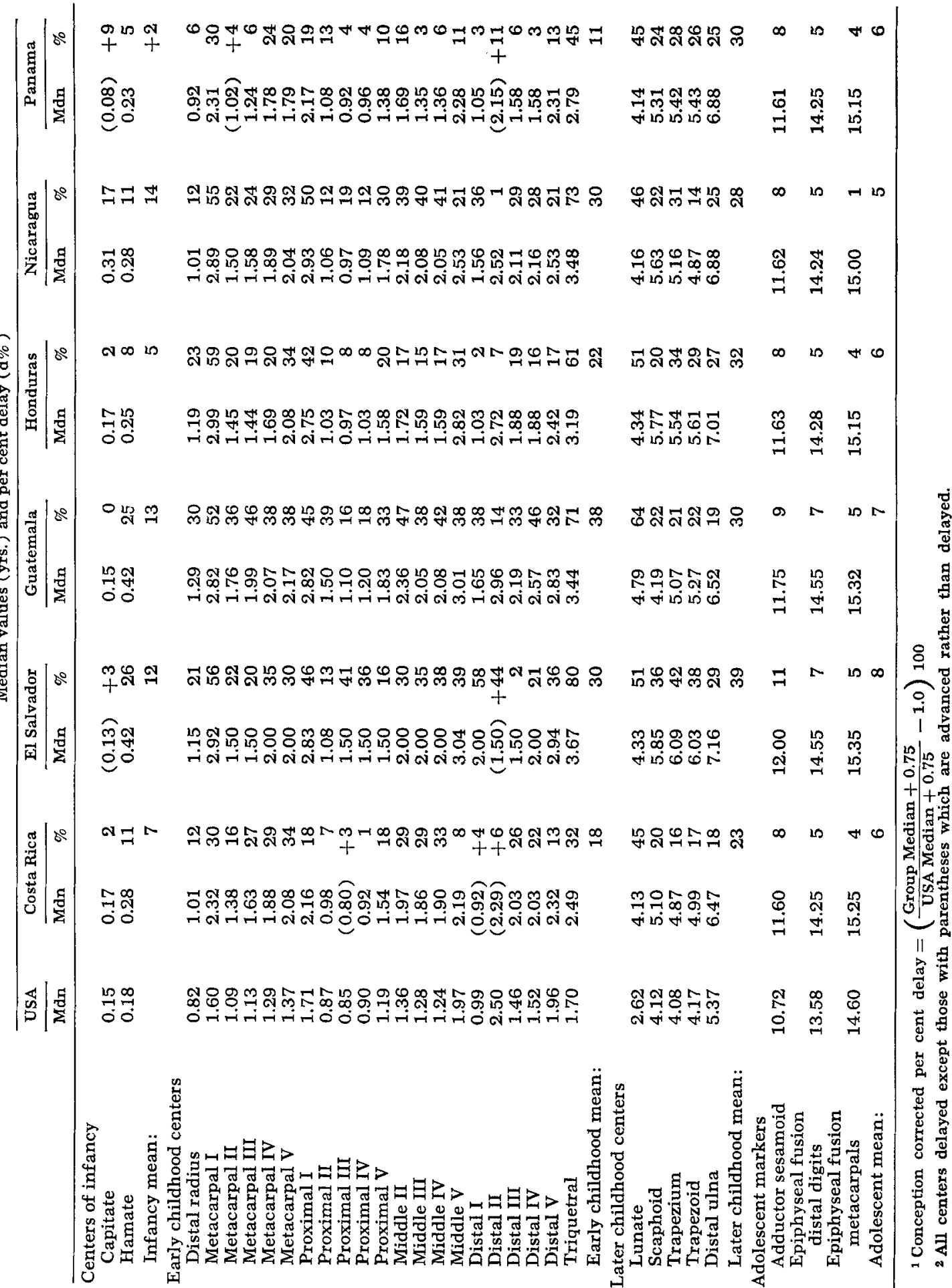



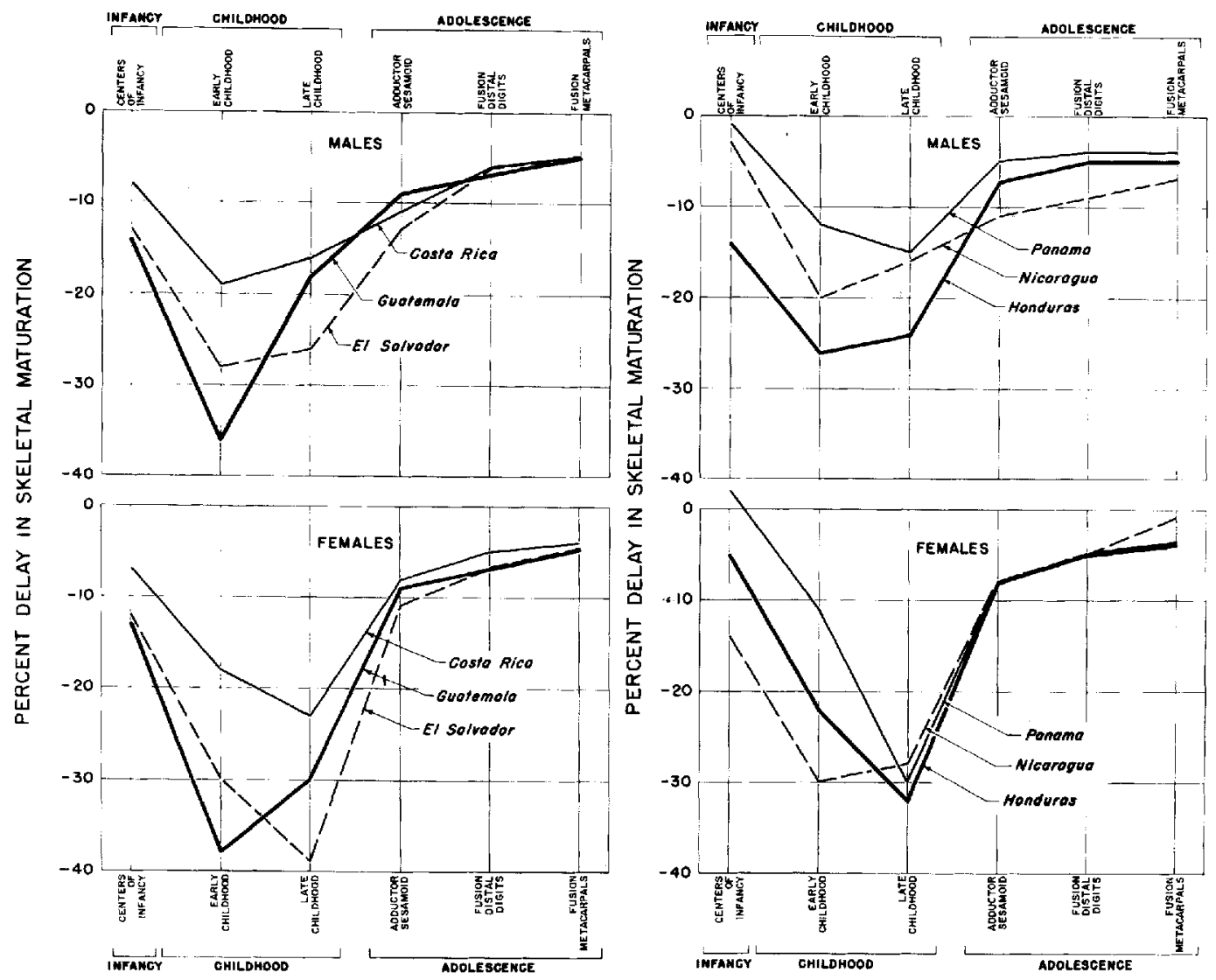

Fig. 1 Skeletal maturation of Central American children expressed as per cent delay with respect to the USA standards. Note that in both males and females, the retardation in skeletal maturation during childhood is systematically greater than that observed during adolescence (see tables 4,5 ).

\section{Body size}

Figure 2 summarizes the development of stature of Central American children compared to the USA standards. From these data, four definite trends can be identified:

a. During the first year of life, Central American and USA children grow at a comparable rate.

b. After the first and second year of age, Central American children grow at a slower rate than the American standard.

c. Central American children show the greatest reduction in body size during the age of 10 and 15 years.

d. Attainment of adult stature in Central American subjects occurs by the age of 18 and 19 years in males and 17 years in females as compared to 17 years in USA males and 16 years in USA females. In other words, the period of growth in Central America has been prolonged by about $7 \%$.

In summary, absolute growth in size of Central American children during the first year of age does not differ from the USA standards. On the other hand, during adolescence, Central American subjects show a maximum reduction in body size. Thus, the reduction in body size in Central America is progressive and does not demonstrate an adolescent "catch-up."

\section{Further evidence}

Sheletal age. In an attempt to test our findings in Central America, we have reevaluated studies of malnourished Asiatic populations in which skeletal maturity and 

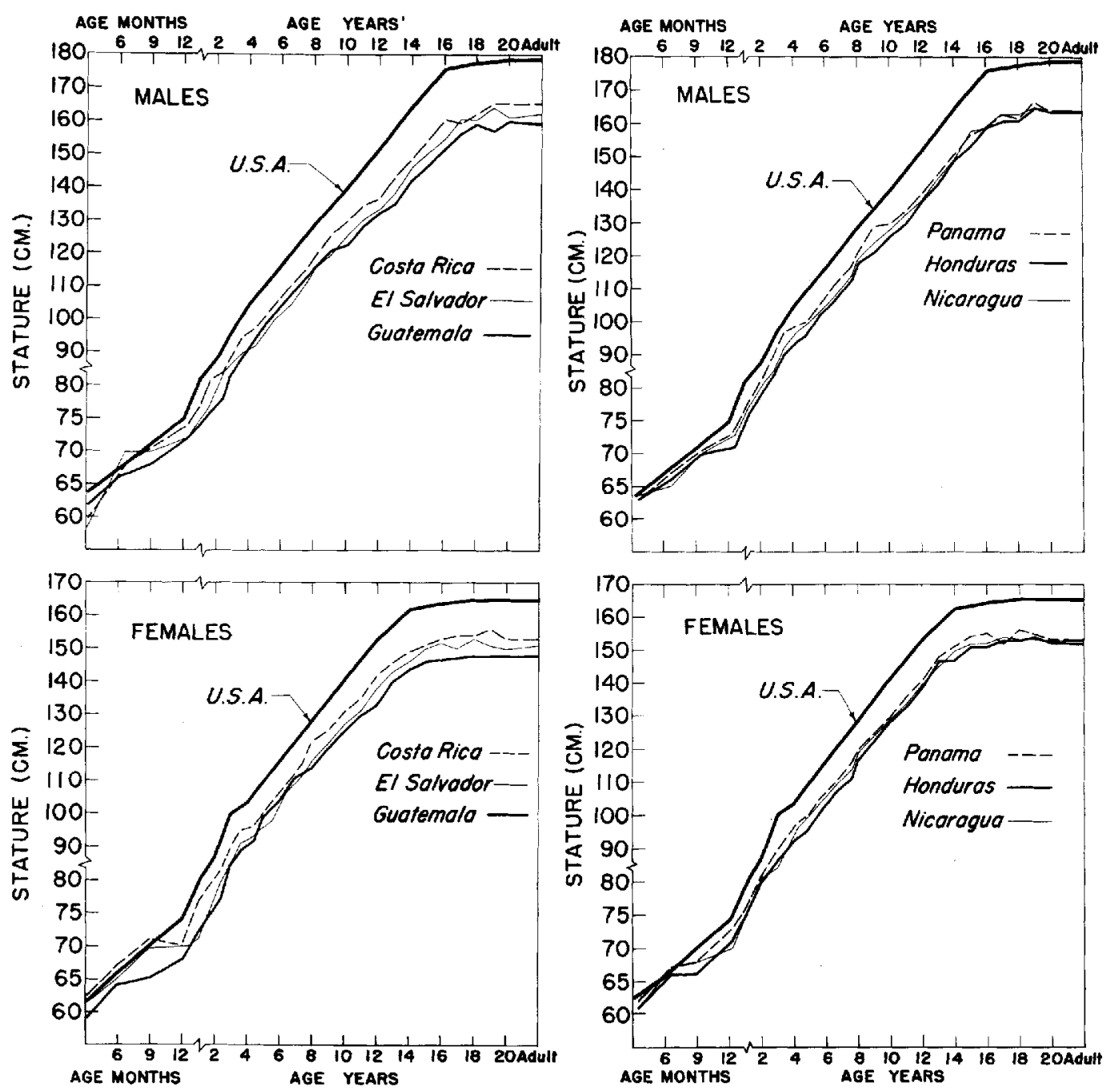

Fig. 2 Development of stature of Central American subjects compared to USA standards. Unlike skeletal maturation, the greatest delay in growth in size occurs during adolescence.

growth in size were assessed simultaneously. The delay in skeletal maturation of Guamanian children (Greulich, '51), native Japanese children (Greulich, '57) and lower class Chinese children (Low et al., '64; Chang et al., '63) were re-analyzed by calculating the per cent delay in skeletal age with respect to chronological age:

Per cent Delay $=\left(\frac{\text { Skeletal Age }}{\text { Chronological age }}-1.0\right) 100$

Since the values for skeletal age were above four years, it was decided not to correct for conception.
As shown in figure 3, despite inter-population differences, in all three countries the per cent delay in skeletal age is systematically greater during childhood than during adolescence. Furthermore, the retardation in skeletal age is comparable in both boys and girls.

Body size and skeletal age. Since children with retarded skeletal maturation at any given age are developmentally younger than advanced children, a logical question, then, is whether Asiatic children at the same developmental status attain comparable body size as the USA standards. With 


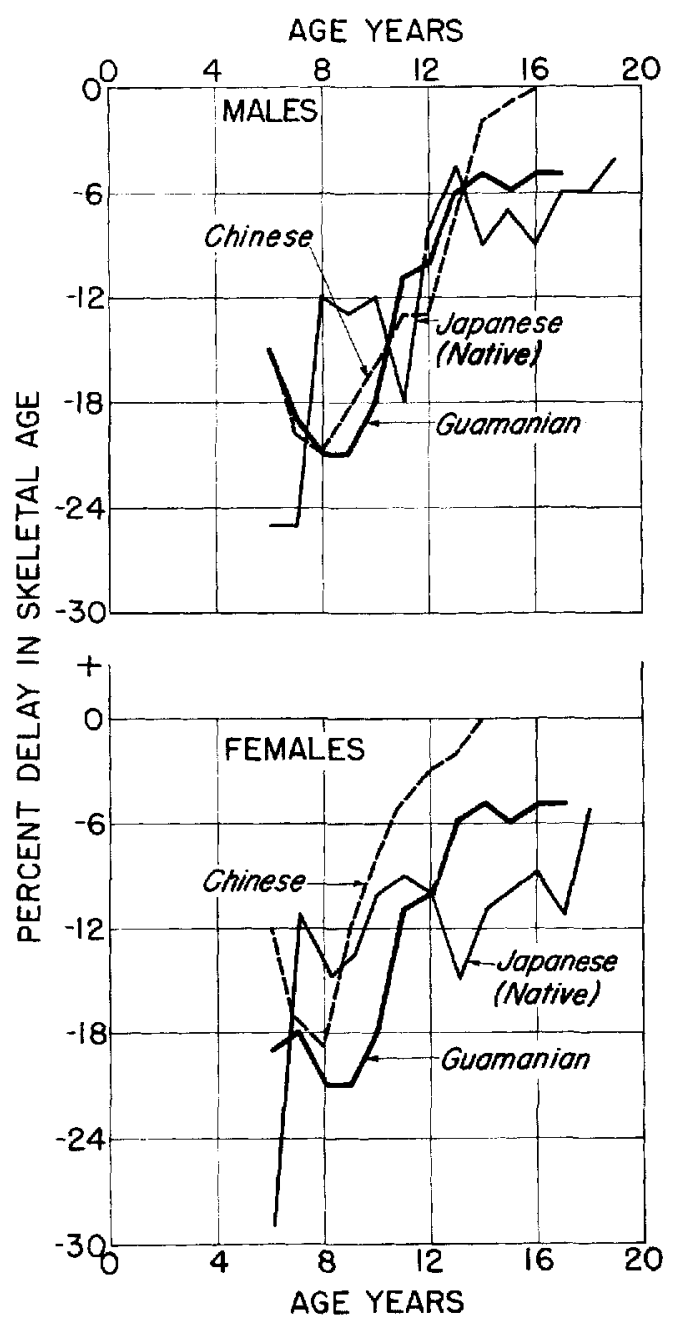

Fig. 3 Skeletal maturation of Asiatic populations. Skeletal age is expressed as per cent of chronological age. As in figure 1, during childhood the per cent delay in skeletal age is systematically greater than that observed during ado. lescence (data calculated from Greulich, '51; Greulich, '57; Low et al., '64; Chang et al., '63).

this purpose in view, we have plotted the stature of Guamanian, Japanese, and Chinese children with reference to their skeletal age rather than chronological age. As shown in figure 4, compared to the USA standards, the Asiatic populations for the same skeletal age are systematically smaller, especially during adolescence, than USA children. Thus, taking differential maturity into account, Asiatic children are smaller in body size than the USA stan- dards, proving the delayed growth for the same maturation status.

\section{DISCUSSION}

With studies on Central American and Asiatic populations agreeing in remarkable form, it is not likely that the present findings are race or population specific. Hence, we can safely state that the effects of chronic malnutrition on skeletal maturation are greater during childhood (especially between the ages of 1 and 10 years)
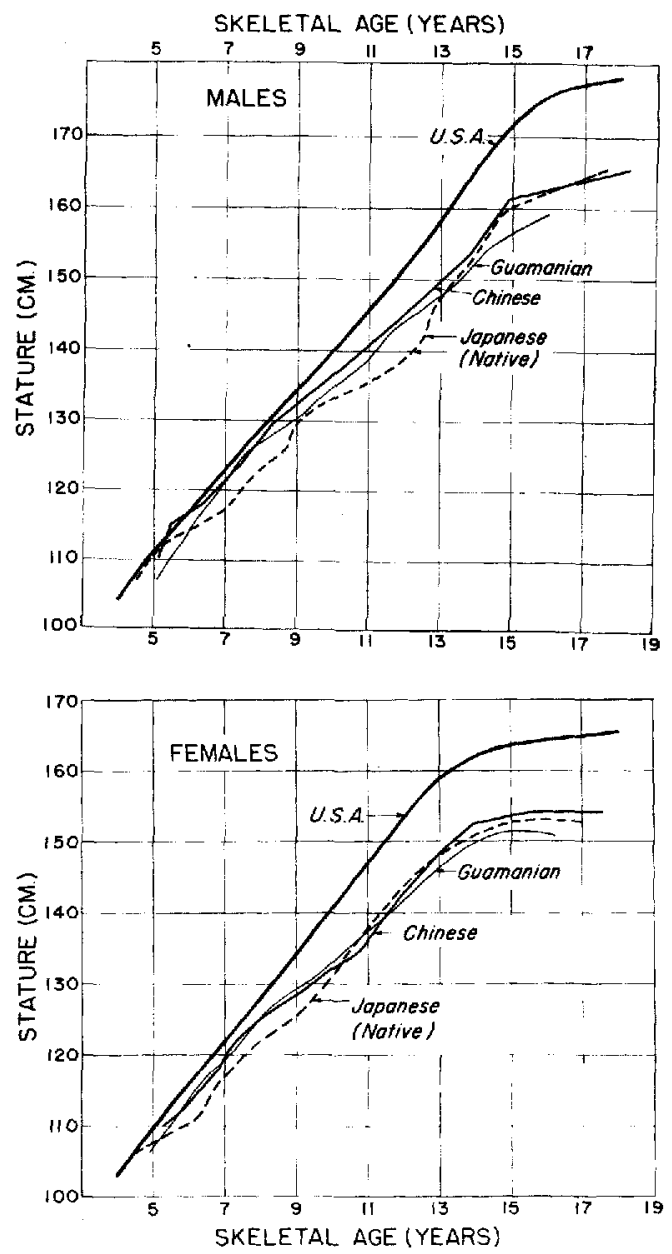

Fig. 4 Development of stature of Asiatic populations in relationship to skeletal age. Note that for the same developmental age (skeletal age), Asiatic children, especially during adolescence, are markedly smaller than USA standards (data reinterpreted from Greulich, '51; Greulich, '57; Low et al., '64; Chang et al., '63). 
than during adolescence. That is, during adolescence, there is an apparent relative improvement in skeletal maturation. In contrast, the anthropometric measurements demonstrate a progressive retardation in growth and lack of an adolescent "catch-up." Furthermore, prolongation of the growth period in Central American populations amounts to only $7 \%$. Thus, the adult stature of Central American populations, as shown in table 6 , exhibits an average reduction ranging from 7 to $10 \%$ in males and females when compared to the USA standards.

The findings of the present study permit us to postulate that the reduction in adult body size of Central American populations is related to the marked childhood retardation and to the fact that during adolescence, the timing of skeletal maturation (especially that of complete epiphyseal union) is less retarded than growth in size. In other words, owing to this unequal influence of chronic malnutrition, the chance for a compensatory growth either through a "catch-up" or by a prolongation of the duration of adolescence is limited. In order to clarify this hypothesis, an understanding of the process of growth and maturation is necessary.

It may be recalled that bone growth in length will continue as long as the interstitial epiphyseal cartilage plate has not been converted into bone (or reached full maturity throughout osteogenesis). In other words, once the epiphyses and diaphyses have been united, growth in length will stop. Consequently, if the timing of complete epiphyseal union is less retarded than growth in size, final adult size will be reduced. This simply is due to the fact that with epiphyseal closure, the potential for continued growth is limited. The hypothe- sis that skeletal maturation is less affected by environmental insult than growth in size is supported by specific animal experimental studies. Acheson ('59), in studying the effects of Pneumococcal septicaemia, indicated that osteogenesis (maturation) at the head of the tibia of rats was not impaired while chondroplasia (growth) was significantly affected, when compared to healthy controls.

It may be noted that the conclusions of the present investigation do not necessarily apply to all conditions of malnutrition, for we know that the consequences of short and acute malnutrition are not the same as those of chronic malnutrition. We know from earlier studies that short and temporary malnutrition followed by an improved diet results in acceleration of growth which compensates for the previous growth failures (Widdowson and McCance, '54; McCance et al., '62; Prader, Tanner and Von Harnack, '63). Furthermore, protein-calorie malnutrition in Central America and Asia is an old story. It is likely that there has been some genetic adaptations to protein lack and to limited amino acids. Consequently, it is quite possible that the slow childhood growth and impaired sexual maturation during adolescence reflect a genetic adaptation as well.

In other words, natural selection in Central America and Asia might have operated throughout malnutrition to favor those with slow growth rates. Where the nutritional resources are limited, the rapidly growing child, due to his higher nutritional requirements, may be expected to be selected out from the population, as occurs in animal experiments (Widdowson, '68). Analysis of the mortality data of 35 localities of Guatemala from 1958 to 1964 indicated that more than 30 per cent of the

TABLE 6

Reduction in adult stature of Central American rural populations with respect to USA standards 1

\begin{tabular}{|c|c|c|c|c|c|c|c|c|c|c|c|c|}
\hline \multirow{2}{*}{$\frac{\text { USA }}{\text { Mean }}$} & \multicolumn{2}{|c|}{ Costa Rica } & \multicolumn{2}{|c|}{ El Salvador } & \multicolumn{2}{|c|}{ Guatemala } & \multicolumn{2}{|c|}{ Honduras } & \multicolumn{2}{|c|}{ Nicaragua } & \multicolumn{2}{|c|}{ Panama } \\
\hline & Mean & $\%$ USA & $\overline{\text { Mean }}$ & $\overline{\% \text { USA }}$ & Mean & $\%$ USA & Mean & $\%$ USA & Mean & $\%$ USA & Mean & $\%$ USA \\
\hline \multicolumn{13}{|c|}{ Males } \\
\hline 178.9 & 165.6 & 7 & 162.0 & 9 & 160.9 & 10 & 164.7 & 8 & 165.0 & 7 & 164.0 & 8 \\
\hline \multicolumn{13}{|c|}{ Females } \\
\hline 165.0 & 153.0 & 7 & 150.0 & 9 & 148.4 & 10 & 152.3 & 7 & 152.8 & 7 & 153.0 & 7 \\
\hline
\end{tabular}

1 Adult values for Central America represent averages for the ages of 20 to 34 years. Means are in centimeters. 
mortality of children under the age of 3 years resulted due to the synergic action of malnutrition and disease (Evaluacion Nutricional de la Poblacion de Centro America y Panama: Guatemala, INCAP, '69, Vol. 25). This could have led to the removal of genes for rapid growth and greater adult stature and leaving of genes for slower growth and shorter adult stature. If this were the case, a genetic basis for the small stature of Central American and Asiatic populations might have resulted from natural selection of those most fitted to survive under limited nutritional sources. Demographic studies whereby the relationship of parental body size and survival of offspring are established would give the answer to this question.

Our findings show that skeletal maturation in Central America is equally delayed and to a considerable degree in boys and girls alike. These findings are in apparent contradiction to the belief that girls are much less affected by unfavorable circumstances (Greulich, '51; Greulich, Crismon and Turner, '53; Trulson, Collazos, and Hegsted, '56; Tanner, '62; Stini, '69). However, it should be realized that skeletal development is itself slower in boys than in girls under normal conditions and to a degree that increases during the first five years of life and then decreases. But when conception-corrected per cent delay is calculated for Central American populations, and per cent delay in skeletal age is calculated for Asian populations, skeletal delay is comparable in the two sexes. Thus, taking differential maturity into account, girls appear to be as much delayed for them as boys are for boys.

\section{ACKNOWLEDGMENTS}

This study was begun under Contract PH-43-65-1006 of the Office of International Research-Nutrition Section and completed under Contract HSM-110-690-22 (National Nutrition Survey) with the $\mathrm{Nu}-$ trition Program, Regional Medical Program Service, Health Services and Mental Health Administration. The computer program for calculating median age-at-appearance of ossification centers was developed by Richard Miller.

The authors wish to thank Fidencio Perez who was responsible for the radio- graphs of the Central American countries: Christabel Rohmann for her competent direction during the radiographic interpretation; Larry McCreery for computer data processing; Harriet McKenzie, Stephen Eklund and Jerrold Nagy for their assistance in manuscript preparation.

\section{LITERATURE CITED}

Acheson, R. M. 1959 Effects of nutrition and disease on human growth. In: Human Growth. J. M. Tanner, ed. Symp. Soc. Study, Hum. Biol., 3: 73-92.

Baldwin, B. T., L. M. Busby and H. V. Gayside 1928 Anatomic growth of children. University of Iowa Studies in Child Welfare, No. 1, University of Iowa, Iowa City, Iowa.

Béhar, M. 1968 Prevalence of malnutrition among pre-school children of developing countries. In: Malnutrition, Learning and Behavior. N. S. Scrimshaw and J. E. Gordon, eds. Massachusetts Institute of Technology Press, Cambridge, Massachusetts.

Björk, A., and S. Helm 1967 Prediction of the age at maximum puberal growth in body height. Angle Orthodon., 32; 44-53.

Buehl, C., and I. Pyle 1942 The use of age at first appearance of three ossification centers in determining the skeletal status of children. J. Pediat., 21: 335-342.

Chang, K. S. F., M. Lee, W. D. Low and E. Kvan 1963 Height and weight of southern Chinese children. Am. J. Phys. Anthrop., 21: 497-510.

Christie, A. 1949 Prevalence and distribution of ossification centers in the newborn infant. Am. J. Dis. Child., 77: 335-361.

Evaluación Nutricional de la Población de Centro America y Panamá 1969 Instituto de Nutricion de Centro America y Panama, INCAP, val, 25-30, Guatemala City, Guatemala.

Flecker, H. 1942 Time of appearance and fusion of ossification centers as observed by roentgenographic methods. Am. J. Roentgenol. Rad. Therapy, 47: 97-159.

Flory, C. 1936 Osseous development in the hand as an index of skeletal development, Monogr. Soc. Res. Child. Develop., 1: 141-181.

Francis, C. C. 1939 Factors influencing appearance of centers of ossification during early childhood. Am. J. Dis. Child., 57: 817-830,

Francis, C. C., and P. P. Werle 1939 The appearance of centers of ossification from birth to 5 years. Am. J. Phys. Anthrop., 24; 273-299.

Frisancho, A. R., S. M. Garn and C. G, Rohmann 1969 Age at menarche: A new method of prediction and retrospective assessment based on hand x-rays. Hum. Biol., 41: 42-50.

Garn, S. M., and C. G. Rohmann 1960 The number of hand-wrist centers. Am. J. Phys. Anthrop, 18: 293-299.

- 1962 The adductor sesamoid of the thumb. Am. J. Phys. Anthrop., 20: 297-302.

Garn, S. M., C. G. Rohmann and B. Apfelbaum 1961 Complete epiphyseal union of the hand. Am. J. Phys. Anthrop., 19: 365-372. 
Garn, S. M., C. G. Rohmann and F. N. Silverman 1967 Radiographic standards for postnatal ossification and tooth calcification. Med. Radio. and Photog., 43: 45-66.

Greulich, W. W. 1951 The growth and developmental status of Guamanian school children in 1947. Am. J. Phys, Anthrop., 9: 55-70.

1957 A comparison of the physical growth and development of American-born and native Japanese children. Am. J. Phys. Anthrop., 15: 489-516.

Greulich, W. W., and S. I. Pyle 1966 Radiographic atlas of skeletal development of the hand and wrist. Second Edition. Stanford University Press, Stanford, Calif.

Greulich, W. W., C. S. Crismon and M. L. Turner 1953 The physical growth and development of children who survived the atomic bombing of Hiroshima or Nagasaki. J. Pediat., 43: 121-145.

Hansman, C. F., and M. M. Maresh 1961 A longitudinal study of skeletal maturation. Am. J. Dis. Child., 101: 305-321.

Hellman, M. 1928 Ossification of epiphyseal cartilage in the hand. Am. J. Phys. Anthrop., 11: 223-257.

Lee, M., S. M. Garn, C. G. Rohmann and P. W. McPhaden 1968 The clustering phenomenon and group sequence of hand-wrist ossification centers, as illustrated by Chinese children in Hong Kong. Hum. Biol., 40: 345-362.

Low, W. D., S. T. Chang, K. S. F. Chang and M. Lee 1964 Skeletal maturation of southern Chinese children in Hong Kong. Child. Develop., 35: 1313-1336.

MacKay, D, H. 1952 Skeletal maturation in the hand: A study of development in East African children. Transactions of the Royal Society of Tropical Medicine and Hygiene, 46: 135-150.

McCance, R. A., J. W. T. Dickerson, G, H. Bell and O. Dunbar 1962 Severe undernutrition in growing and adult animals. Brit. J. Nut., 16: 1 .

Prader, A., J. M. Tanner and G. A. Von Harnack 1963 Catch-up growth following illness or starvation; an example of developmental canal ization in man. J. Pediat., 62: 646-659.

Reynolds, E. L., and T. Asakawa 1951 Skeletal development in infancy: Standards for clinical use. Am. J. Roentgenol. Rad. Therapy, 65: 403409 .

Ruckensteiner, E. 1931 Die normale entwicklung des knochensystems im rontgenbild. George Thieme, Vienna.

Sontag, L. W., D. Snell and M. Anderson 1939 Rate of appearance of ossification centers from birth to the age of five years. Am. J. Dis. Child., 58: 949-956

Stini, W, A. 1969 Nutritional stress and growth: Sex difference in adaptive response. Am. J. Phys. Anthrop., 31: 417-426.

Sutow, W. W. 1953 Skeletal maturation in healthy Japanese children, 6 to 19 years of age: Comparison with skeletal maturation in American children. Hiroshima J. Med. Sci., 2: 181-191.

Tanner, J. M. 1962 Growth at adolescence. Second Edition. Blackwell Scientific Publications, Oxford.

Thsala, R., R. L. Kantero and L. Backstrom 1966 The appearance pattern of skeletal epiphyses among normal Finnish children during the first five years of life. Ann. Paediat. Fenn., 12: 64-72.

Todd, T. W. 1937 Atlas of skeletal maturation (hand). C. V. Mosby Co., St. Louis, Missouri.

Trulson, M. F., C. Collazos and C. M. Hegsted 1956 Growth and development of Peruvian children. I. Carquin and San Nicolas. Pediatrics, $17 ; 510-523$.

Widdowson, E. M. 1968 The place of experimental animals in the study of human malnutrition. In: Calorie deficiencies and protein deficiencies. Churchill, London.

Widdowson, E. M., and R. A. McCance 1954 Studies on the nutritive value of bread and on the effect of variation in the extraction rato of flour on the growth of undernourished chil dren. Med. Res. Council Spec. Rep., Ser. No. 287. 